\title{
Public Use and Landscape Analysis in the Serra da Canastra National Park, Brazil: A Geospatial Approach
}

\author{
Marcos Cicarini Hott'1,2, Luiz Otávio Moras Filho, \\ Marco Aurélio Leite Fontes ${ }^{1 *}$, Aline Aparecida Silva Pereira ${ }^{1}$, \\ Cláudia de Oliveira Gonçalves Nogueira1, \\ Luis Marcelo Tavares de Carvalho', Luís Antônio Coimbra Borges', \\ João Cesar de Resende ${ }^{2}$, Mauro Antonio Homem Antunes ${ }^{3}$ \\ ${ }^{1}$ Department of Forest Sciences, Federal University of Lavras, Lavras, Brazil \\ ${ }^{2}$ Brazilian Agricultural Research Corporation-Embrapa, Juiz de Fora, Brazil \\ ${ }^{3}$ Department of Engineering, Federal Rural University of Rio de Janeiro, Seropédica, Brazil \\ Email: *fontes@dcf.ufla.br
}

Received 22 January 2016; accepted 26 February 2016; published 29 February 2016

Copyright (C) 2016 by authors and Scientific Research Publishing Inc.

This work is licensed under the Creative Commons Attribution International License (CC BY). http://creativecommons.org/licenses/by/4.0/

(c) (i) Open Access

\begin{abstract}
The Conservation Units (CU) were created to protect natural environments from growing degradation and to impede the expansion of urbanization and agricultural crops. The Serra da Canastra National Park, established to protect the headwaters of the São Francisco River and other places of scenic and ecological interest, is extensively visited due to its many tourist attractions, such as waterfalls, fauna and flora. An analysis of the park's geography is needed to assess the risk involved in and its suitability for public use due to its territorial extension and environmental complexities. Thus, this study aimed to investigate the background of issues of interest to $\mathrm{CU}$ management. Additionally, we used high-resolution RapidEye imagery, altimetry and database of park infrastructure to build geospatial database and estimate classes of suitability for and risk in public use through GIS tools. The resulting cartographic data can support the planning of policies concerning the landscape and park's territorial management.
\end{abstract}

\section{Keywords}

Conservation Units, Environment, GIS, RapidEye Imagery

\footnotetext{
"Corresponding author.
}

How to cite this paper: Hott, M.C., Filho, L.O.M., Fontes, M.A.L., Pereira, A.A.S., Nogueira, C. de O.G., de Carvalho, L.M.T., Borges, L.A.C., de Resende, J.C. and Antunes, M.A.H. (2016) Public Use and Landscape Analysis in the Serra da Canastra National Park, Brazil: A Geospatial Approach. Natural Resources, 7, 93-101. http://dx.doi.org/10.4236/nr.2016.72009 


\section{Introduction}

The accelerated advance of anthropogenic interventions has led to increasing concerns about the impacts on natural environments, suggesting a need for government planning in favor of socioeconomic and environmental balance. Therefore, it was incumbent upon the government to create "specially protected areas" across the country; these areas are public or private areas endowed with environmental attributes that require special legal rulings, ensuring their relative immutability and sustainable use [1]. Also the improved technical capacity in mapping the distribution and extent of riparian forests is needed, in the case of permanent preservation areas in Brazil, and the boundaries of private properties [2]. Thus Conservation Units (CU) were created as areas with "relevant natural characteristics, legally instituted by the Government, with conservation goals and limits defined under special administration ruling, to which are applied appropriate guarantees of protection" [3]. A Brazilian law classifies these areas according to the different degrees of conservation and specifies the elaboration of a Management Plan. These areas are classified according to the different degrees of conservation in Federal Law No. 9985/2000, which establishes the National System of Conservation Units (SNUC-Portuguese acronym). To ensure the effective protection of these areas, the law specifies the elaboration of a Management Plan, a technical document that establishes the zoning and other rules that guide the use of each CU and the management of natural resources, including the building of physical structures required to manage the unit. For units where visitation is allowed, a Public Use Plan must be integrated into the Management Plan to ensure the conservation of its natural, historical and cultural resources; visitors' awareness of nature; and a return of benefits for the local communities [4]. However, most CU does not reach the appropriate level of efficiency, mainly due to disputes, invasions, deforestation and fires, which reflect the difficulty of the land regularization process of these areas [5]. However, despite overall issues of lack of interconnections or coordination between the institutions, the Brazilian tourism presents significant progress occurring in northeast region [6] [7]. The Serra da Canastra National Park (SCNP) [8] is composed of two areas: 1) Chapadão da Canastra, with its land regularized and open to visitors with the main attractions of the park; and 2) Chapadão da Babilônia, which has non-regularized land and visitation restrictions. Among the main attractions of the regularized area of the park are the historical headwaters of the São Francisco River, the Curral de Pedras (a stone stockyard that is a vestige of an old farm), and the Rolinhos and Casca D'anta waterfalls, which are visited annually by approximately 40,000 visitors, who enter one of four entrances to the park. The park should have included a Public Use Plan in its Management Plan [9]. However, the absence of these guidelines has led to the degradation of most trails. Highspatial resolution maps can be elaborated from satellite imagery, for example, to preserve parks of historic heritage [10] or in planning of trails, as made by [11] in mapping of trails and studies of its degradation in a park in Poland.

The geospatial approach in public use planning in CU demands physical-environmental characterization and understanding of the legal context. Public use is considered as "educational, recreational, and environmental interpretation activities, performed in contact with nature according to specifications in the management plans of the conservation units" [12]. Its main objective is to provide visitors the opportunity to learn, in a playful way, the attributes and the environmental values safeguarded by $\mathrm{CU}$ whether public or private.

According to [13], the concept of public use can include various types of use: Recreational, Commercial, Scientific, Educational and Personal development. Article 7 of Federal Law No. 9985/2000 [3] divides CUs into two groups in accordance with main purpose: Integral Protection Units, and Sustainable Use Units. The need for CU emerged due to the 1971 drought in the region. The drought was associated with deforestation caused by the construction of the Furnas reservoir and logging by other companies, culminating in the stoppage of navigation in the São Francisco River. Faced with these problems, the Brazilian Institute for Forestry Development (IBDF - Portuguese acronym), the federal agency responsible for administering national parks and biological reserves at that time [14], conducted emergency studies to evaluate the technical, financial and social conditions to establish this CU.

Thus, the SCNP was created in 1972, which established a territorial domain estimated at 200,000 ha covering the areas denominated as Chapadão da Canastra and Chapadão da Babilônia. However, strong resistance from the community that occupied the areas that would be expropriated forced the federal government to declare priority areas of interest for agrarian reform within CU in 1974. The expropriation process generated a series of conflicts based mainly on the price of the land and infrastructure stipulated by the National Institute of Colonization and Agrarian Reform (INCRA), which, according to the populations of the expropriated areas, did not correspond to the proper value. As a result, a study was commissioned that supported a counterproposal, primar- 
ily addressing compensation and reduction of the park boundaries. This reduction was proposed due to the exclusion of agrarian land on the perimeter of the park.

Between 1976 and 1980, numerous conflicts took place in this region, culminating in the destruction of 90\% of the park area caused by criminal fires, requiring the intervention of Federal Police. The effects of these land conflicts have been felt until now, hindering full implementation of the national park.

The SCNP is located in the southwest of Minas Gerais State covering parts of the territories of six municipalities (Table 1). The national park has a visitor center and, in addition to the São Francisco headwater, several tourist attractions, and due to agrarian issues aimed to solve this territorial question with Federal Decree No. 74446/1974 [15] and No. 74447/74 [16].

The temperatures in the region are mild, with an average of $17^{\circ} \mathrm{C}$ and $23^{\circ} \mathrm{C}$ in winter and summer, respectively. The annual precipitation index varies between 1300 and $1700 \mathrm{~mm}$, with rainfall concentrated in the period from December to February. The landscape of the park has basically alternating plateaus, scarps and defined valleys. Two major segments of the park can be identified. In the first, the broad plateau of Canastra's massif represents the predominant physiognomy, covered by grassland formations. In the second, with rugged relief and corresponding to the region of Chapada da Babilônia, are alternating relief bands that feature scarps and elongated valleys [9]. Characterized by high altitudes (from 700 to over $1400 \mathrm{~m}$ ), the two massifs, Canastra and Babilônia, form the cradle of a hydrographic system that is represented by water courses that drain into the São Francisco, Grande and Araguari rivers. These rivers receive a large number of smaller tributaries, many of which have headwaters inside the park. Concerning vegetation, the park is located in the Cerrado phytogeographical domain (Brazilian savannah), characterized by small and medium-sized trees, thick bark and twisted branches, well-adapted to poor soil and resistant to drought and fire, whose vegetation phenology is studied by various scientists [17]-[19]. Forest formations in the region have suffered varying degrees of change because of the uses before the creation of CU, particularly the use of fire for grassland management. Some remaining trees of the primary conditions can be found but most forest cover is in the secondary stage [20]. Faced with the abiotic and biotic factors, it can be affirmed that the park is highly important in protecting and conserving the natural and cultural resources of the region, highlighting the need for regularization of the CU boundaries, mainly, due to influence of mining areas adjacent to protected areas [21].

Serra da Canastra National Park was chosen as the subject of this study aiming to analyze the suitability of and risk in the use of its space because it is a category of CU that allows public use, as Sustainable Use Unit. This research aims to subsidize the planning of visits through weighting physical-environmental and structural factors with consideration of geographic and agrarian aspects, in addition to the occupation of the territory.

\section{Methods}

A classic definition of GIS (Geographic Information System) was made by author Stanley Aronoff, which wrote in your Canadian publication in 1989 that GIS is, simply, "any manual or computer based set of procedures used to store and manipulate geographically referenced data", thus, defining in way fully and easy this system. GIS can generate large amounts of information using remotely sensed data, which can be processed in imagery processing software [22]-[24], providing the resources land cover and use analysis. GIS is software with tools for geospatial information processing to generate digital maps and thereby enables decision making and planning in the use of natural and anthropogenic resources. These tools might help in several participatory studies

Table 1. Municipalities covered by the CU and the percentage of the municipal area.

\begin{tabular}{cc} 
Municipality & Percentage of the municipality overlapped by SCNP \\
\cline { 2 - 2 } São Roque de Minas & Area (\%) \\
Sacramento & $41.13 \%$ \\
Delfinópolis & $02.46 \%$ \\
São João Batista do Glória & $40.30 \%$ \\
Capitólio & $46.51 \%$ \\
Vargem Bonita & $18.78 \%$ \\
\hline
\end{tabular}


about land use change trajectories, and biodiversity assessments aiming the restoration of protected areas, as in the case of areas in Nicaragua [25]. [26] identified the extraction and redistribution of water at artificial points across desert in protected areas in Chad, which can constitute a real threat to local ecosystem dynamics, using open GIS tools and Landsat satellite imagery, freely, distributed. Through remote sensing data, GIS can generate large amounts of information. The decision support by Multicriteria is widely used by authors in suitability analysis and land-use where integration with GIS is fundamental to obtain quick results and the possibility of repeat operations with numerous maps of interest [27]-[30]. These GIS operations aim to identify a sum that is an index for risk from or suitability to a specific activity, weighted by factors considered important for the studied phenomena. In general, weighting is applied, resulting in a potential range [31]. [32] found improvement in the weighted analysis for mapping through GIS for artificial groundwater recharge in arid regions in Egypt, with more precision in comparison with Boolean operations. These factors will influence the final result and the scores or gradations distributed throughout the geographic space of analysis. To study the important factors in geographic analysis concerning the $\mathrm{CU}$, we examined the database provided by the park management, using the appropriate tools, aiming to analyze the park area and suitability for public use.

Park extension was analyzed through RapidEye imagery from 2012 (Figure 1). The Universal Transverse Mercator (UTM) projection, zone 22 south, and the SIRGAS2000 Datum (Geocentric Reference System for the Americas) were used. The official park area of 197,788 ha and the effective area for regularized public use 71,360 ha were demarcated near the limits of municipalities of São Roque de Minas and São João Batista do Glória.

However, principally, due to large extension of area of public use the absence of guidelines for utilization has led to the degradation of most trails, including the trail that links the higher and lower parts of Casca D'anta waterfall, the park's main attraction. Therefore, this study uses RapidEye imagery (provided by GeoCatálogo in the website of Brazilian Institute of the Environment and Natural Renewable resources-IBAMA), in GIS to determine suitable areas for public use by an additive multicriteria method based on weighted overlay of geospatial data provided by ICMBio (Chico Mendes Institute for Biodiversity Conservation) and other information availa-

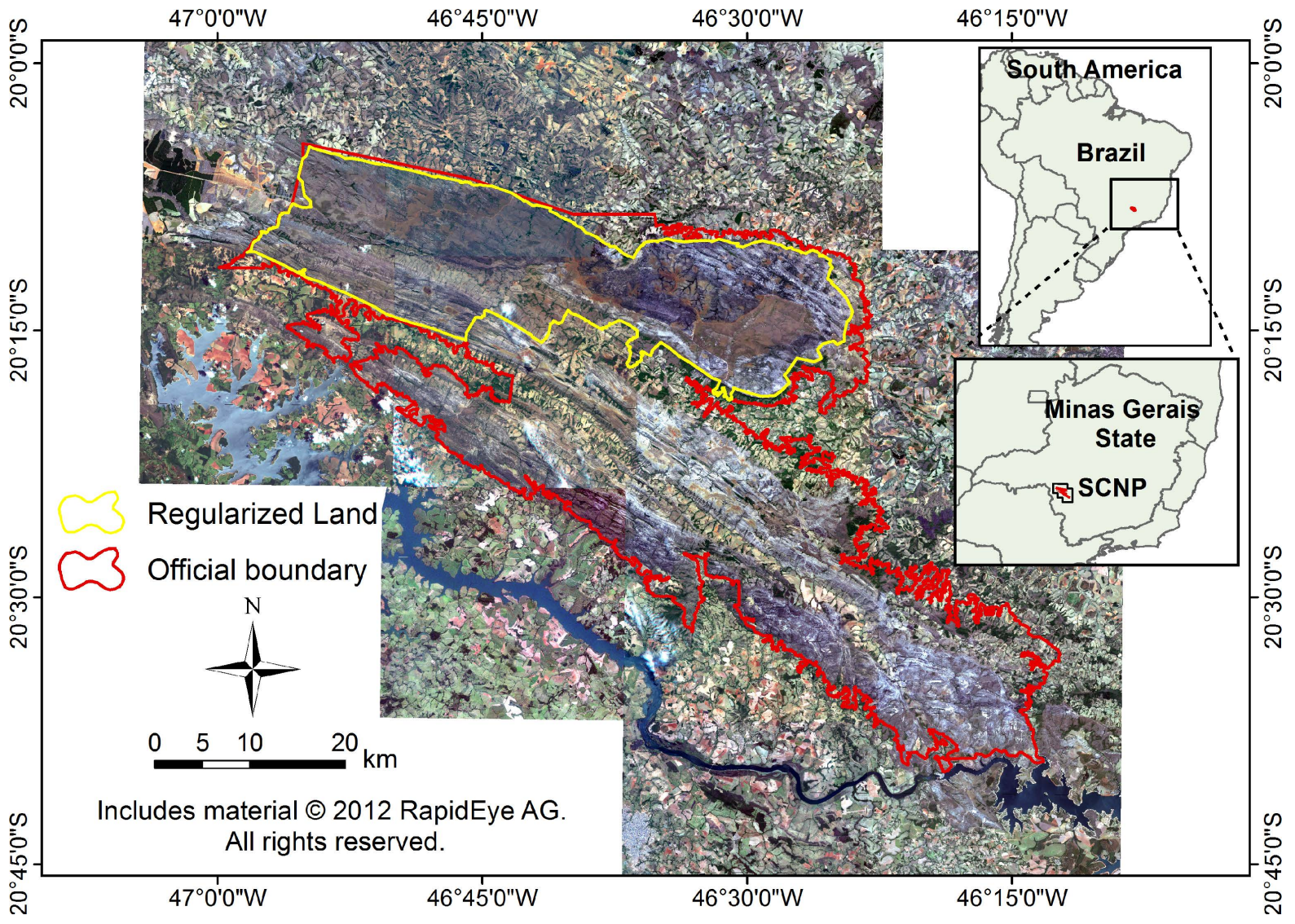

Figure 1. Area of park overlapped to RapidEye imagery. 
ble in remote sensing databases. The high-resolution images enabled the visualization and general characterization of the park in relation to the distribution of features, vegetation, relief, and overlapped mapped infrastructure, with this iconographic base useful in classification of land-use/land-cover, managing, and planning the CU.

Due to the rugged relief, the altimetry information was essential for decision making regarding the tourist pathway in the CU. These data were obtained from a Digital Elevation Model (DEM) of the regularized use area from the Shuttle Radar Topography Mission (SRTM) [33]. A slope map generated from the DEM was used in the risk and suitability analysis for public use, in addition to the visitation points, entrances, access roads, and hydrograph in the area of regularized use. All layers are combined to classify areas that provide better access to available resources and appropriate access conditions. Mathematical decision and evaluation models provide tools for analyzing the complex solutions between alternatives with several environmental impacts. The formal mathematical framework used to describe multidimensional decision-making is based on multi-objective optimization theory in which both conflicting and complementary objectives are presented as a decision problem with multiple objectives [27]. According the indication of the area through a process of map overlay, the issue is presented to stakeholders that concern the identification of objectives on the basis of an evaluation of a defined number of choice alternatives by a limited number of attributes, while considering subjective scales of understanding. The outcome classes in multicriteria refer to any ranged value in the total area. As undefined rule, most developed techniques and analyses have been developed for evaluating small numbers of choice alternatives on the basis of only a limited number of criteria. Many problems of spatial search will involve a much larger range of alternatives and criteria, necessitating the modification and automation of methods. Some consideration of the weighted multicriteria techniques adapted here for utilization in the GIS is required to explain how the decisions and scores work.

To generate a map of suitability for public use, we used the Additive Multicriteria method [34]. The method integrates GIS, remote sensing data and decision criteria, using raster data format, assigning weights and scores to the variables of interest and placing them in a decision algorithm:

$$
A_{i j}=\sum_{k=1}^{n}\left(P_{k} \times N_{k}\right)
$$

where

$A_{i j}$ is a pixel of the raster map;

$n$ is the number of layers;

$P$ is the layer weight;

$N$ is the layer score.

In the Additive Multicriteria process was adopted scores between 1 and 7, with the smaller scores indicating the most appropriate slopes or distances for public utilization, traffic, security and proximity to points of interest. The following weights were assigned to each information layer: 0.35 for the slope, 0.25 for the distance-to-road, 0.20 for the distance-to-hydrography, 0.15 for the map-to-main-touristic-points, and 0.5 for the distance-to-entrances. These weights amounted to $1(100 \%)$ in the computation of factors that influence the geographic phenomenon of suitability for utilization.

\section{Results}

Proposals for the creation of new trails and tourist attractions were made to minimize the impacts of visitors who access the waterfalls and trails and to provide the visitors education and recreation. The correct carrying capacity of these trails and attractions regarding the degradation risk posed by proximity to farming communities should be observed, in addition to their typical phytophysiognomy, as the Cerrado, which is susceptible to fires (Figure 2).

The problems presented by the park management showed the need for research on solutions to improve the current trails and create new ones to reduce the impact on current trails and distribute visitors among the trails and attractions.

The proximity to roads, water, and lower slope classes made it extremely important to identify the areas with higher suitability for public use or reducing traffic in the CU area. The proximity to the main tourist points and support points (represented by entrances) was defined as the lowest weight for the trafficability in this area because these points already have associated access routes, which are given greater weight in this analysis (Figure 3). 


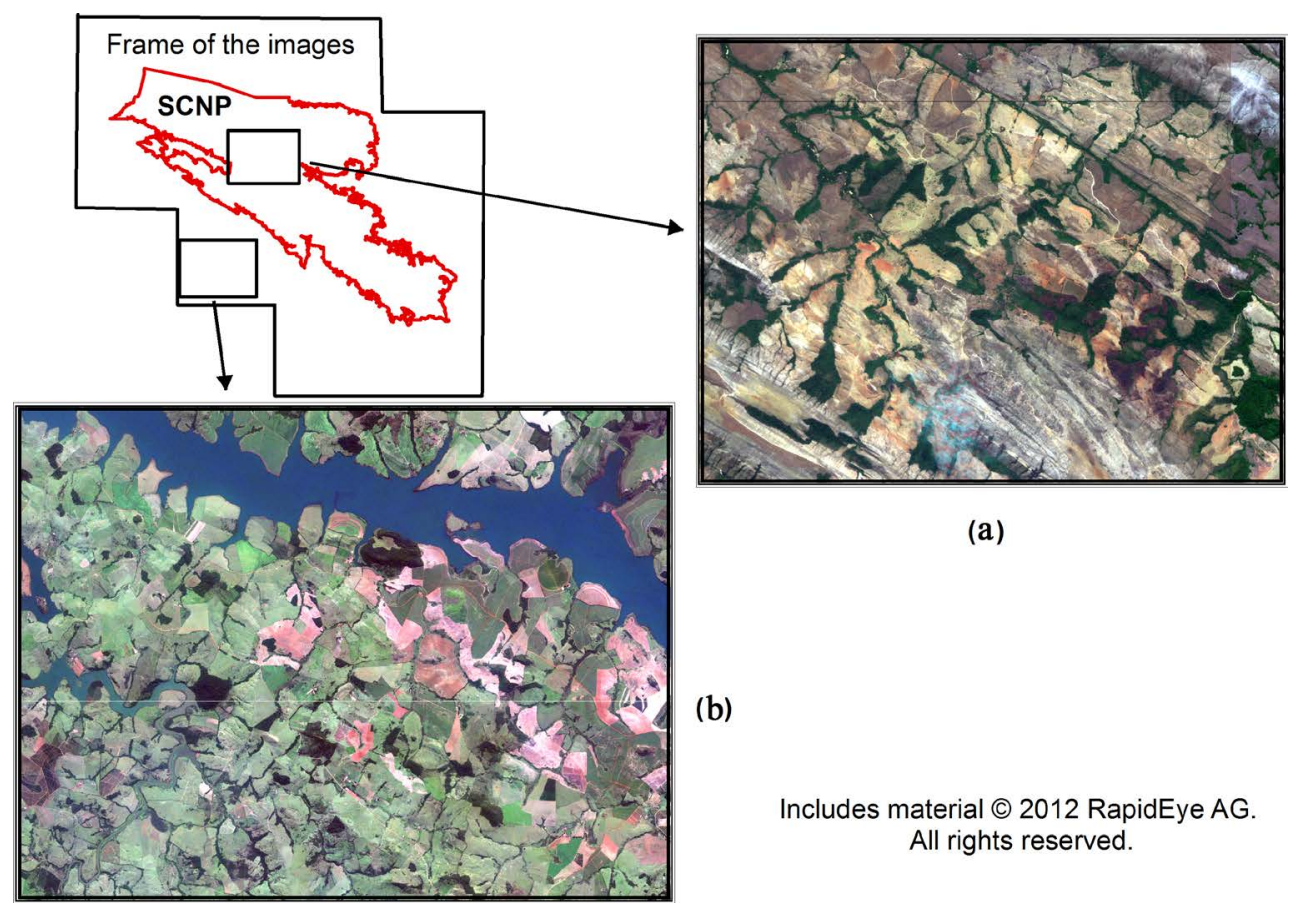

Figure 2. (a) Typical phytophysiognomy of landscape; (b) and surrounding areas with agricultural use.

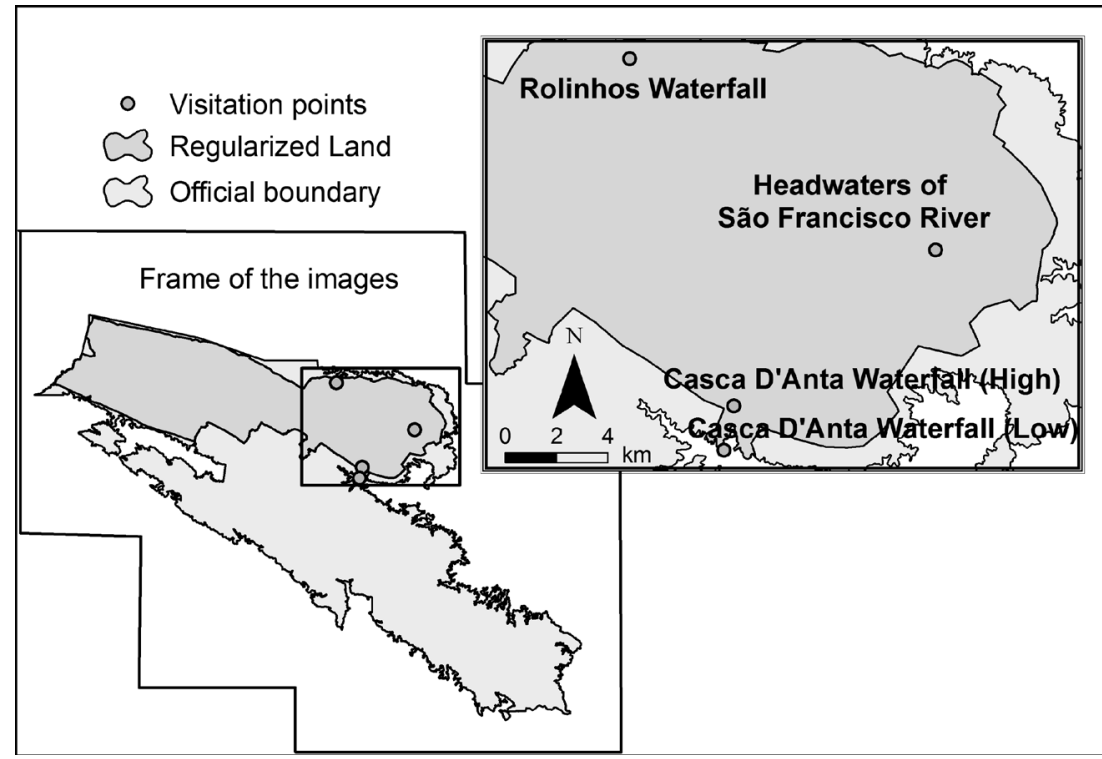

Figure 3. Location of important tourist points in the conservation unity.

Important factors in suitability for public visitation are the possibility of fires in the area, proximity to roads, water and faster traffic routes. Thus classes were generated considering proximity to access and water availability, as well as support points, visitation points, and especially class of slopes (as friction maps, in a possible optimization analysis, or cost maps, for potential generation of trails).

The Figure 4 shows the distribution of areas with classes for suitability of use from the regularized area. Most of the park regularized area is of "Moderate" use (32.74\%), where, even away from the points of visitation or support, there are low slopes and good proximity to roads and hydrography. The "Very High" suitability and use classes showed a small percentage of areas with low slopes and proximity to roads while the "Extremely Low" presented high slopes with low proximity to roads. 


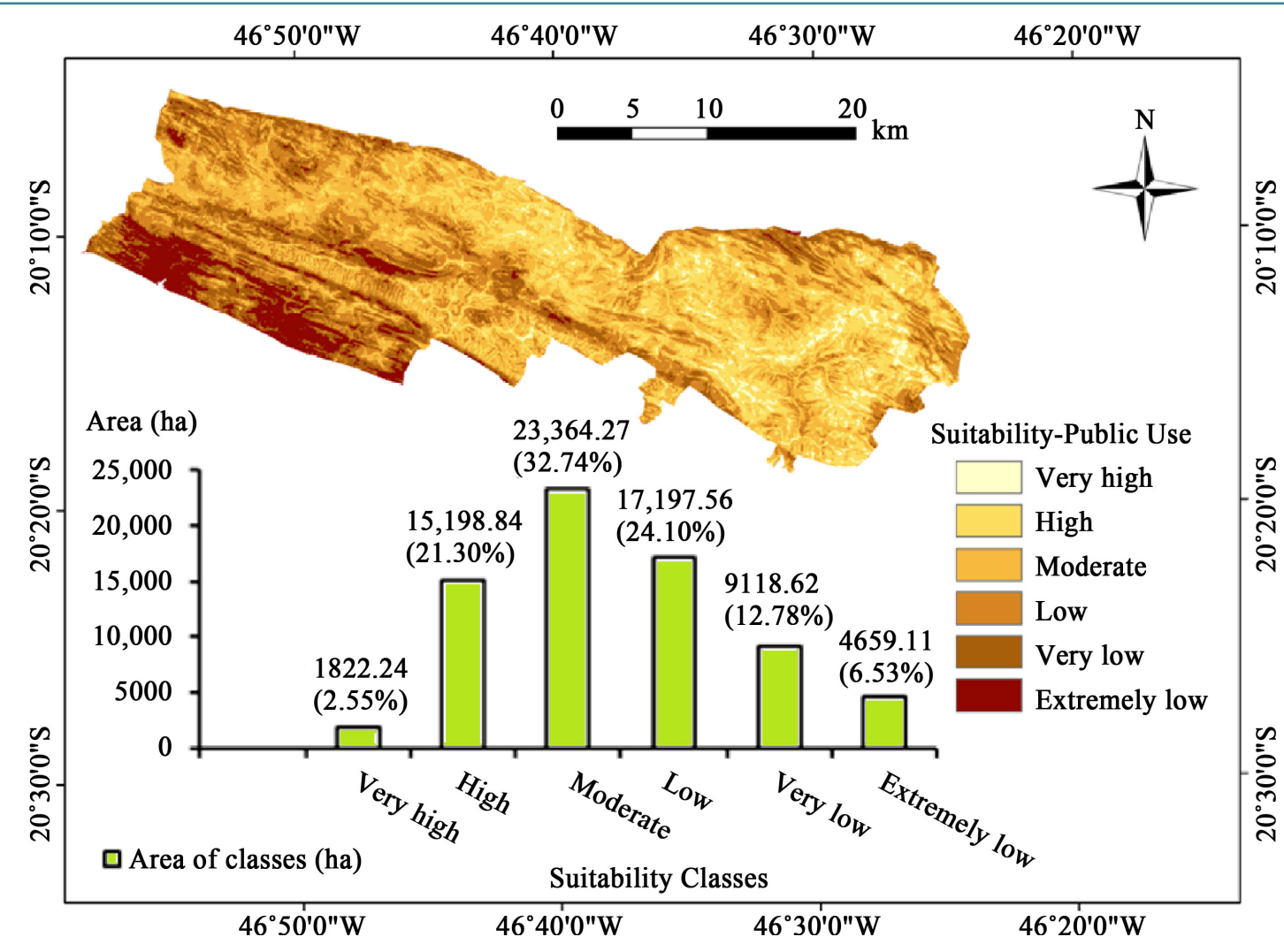

Figure 4. Area of suitability and recommendation classes for public use and distribution per area and percentage.

\section{Discussion}

The SCNP does not have yet a definitive Public Use Plan. However, educational activities are currently held in the Visitors Center, near Entrance \#1. According to [20], the regularized park area is open to visitors, with monitoring of the main attractions: the Casca D'Anta waterfall, the Rolinhos waterfall, the historical headwaters of São Francisco River and the Curral de Pedras. These attractions receive approximately 40,000 visitors each year coming from the four entrances. The park has 52 trails open for fire control and biodiversity maintenance, but only the trail of the Casca D'Anta waterfall is being used for tourist activity.

Trails open to visitors are degraded, requiring urgent recovery due to unfavorable trail conditions, Casca D'Anta waterfall is the only attraction that is monitored, with only 50 visitors allowed per day; this limit has been established because of several erosion gullies, environmental risk and the risk for visitors injuries.

The criterion of weight distribution in the additive multicriteria method, often subjective, is being the major limitation of the method. Depending on the number of maps, the determination becomes more difficult, requiring deep knowledge of the geographical parameters and factors that influence the studied phenomena. The definition of scores assigned to grades or classes on each map is also a source of subjectivity. The distribution of data and the characteristics of the mapped information are always observed, according to what the researcher judges important in facilitating the activities and their thresholds, as for example in the determination of distance classes to roads.

\section{Conclusions}

RapidEye imagery favored the analysis of the geospatial context of the CU with an accurate view of the features of interest in the landscape, allowing vegetation recognition, topographic variation perception, and advancement of human activities around the national park. The overlapping of available geospatial layers with the imagery guided the selection of a methodology that suits the weighting required by GIS and future analysis, with new layers to be listed. From the formation of a new satellite database, new land-cover classification methods may be indicated to better understand the geography of the park, in addition to the decision criteria in GIS and interpre- 
tation applied to the management plan. The RapidEye imagery greatly facilitated detailed viewing of the environment, needed in the analysis process. The use of remote sensing data and GIS provided important information for management and a synoptic view of the environmental and morphometric aspects of the park and the geographic locations of visitation and support points, roads and hydrograph. The methodology of data analysis allowed mapping and defining areas that are more favorable for visitation. In addition to other layers, such as visibility and vegetation cover, this method can enable more accurate planning of new trails in the park. The functions and analytical capabilities of GIS can facilitate decision making and feedback on the CU management plan because it easily integrates satellite imagery, particularly high-resolution imagery as RapidEye, and their combination with the hydrography, roads, points of visitation and points of interest, in addition to DEM and slope map.

According the Figure 1 and Figure 4 are shown that the extension of its area is too large and the "Moderate" class dominates the results of analysis of Multicriteria, respectively. The dimension or percentage of results of "Moderate", "Very High", and "Extremely Low" of the classes of suitability demonstrated the normal distribution of map obtained. It was demonstrated that despite diverse cartographic themes used in the analyses of landscape, and composite of database for subsidize the public use, the utilization of the procedures and methods of sampling stochastic have potential for management of this park. Large geographic database generated demands interoperability due to geographic systems used by the institutions involved. After these analyses we have robust information to follow the steps in the review of a management plan and public use, aiming full use, with the sustainability of natural resources available in the CU.

\section{Acknowledgements}

We thank the Federal University of Lavras, Chico Mendes Institute for Biodiversity Conservation-ICMBio, Brazilian Institute of the Environment and Natural Renewable resources-IBAMA, and Brazilian Agricultural Research Corporation-Embrapa for supporting this research.

\section{References}

[1] Silva, J.A. (2000) Direito ambiental constitucional. 3rd Edition, Malheiros, São Paulo.

[2] Nunes, S.S., Barlow, J., Gardner, T.A., Siqueira, J.V., Sales, M.R. and Souza, C.M. (2015) A 22 Year Assessment of Deforestation and Restoration in Riparian Forests in the Eastern Brazilian Amazon. Environmental Conservation, 42, 193-203.

[3] Brazil (2000) Lei n. 9.985, de 18 de julho de 2000. Regulamenta o art. 225, § 1o, incisos I, II, III e VII da Constituição Federal, institui o Sistema Nacional de Unidades de Conservação da Natureza e dá outras providências. Senado Federal, Brasília. http://www.planalto.gov.br/ccivil_03/leis/L9985.htm

[4] Krob, A.J.D. (2003) Plano de Uso Público para o Parque Nacional Marinho dos Abrolhos. http://www.icmbio.gov.br/parnaabrolhos/images/stories/downloads/Plano_de_Uso_Publico_-_Parque_Nacional_Marin ho_dos_Abrolhos.PDF

[5] IBAMA and WWF (2007) Management Effectiveness of Brazil's Federal Protected Areas: Implementation of the Rappam Methodology: Rapid Assessment and Prioritization of Protected Area Management. Onaga, C.A. and Drumon, M.A., Org., Almeida, A.C.G., Trans., MMA, Brasília, 95 p.

[6] Araújo, L.M. and Bramwell, B. (2002) Partnership and Regional Tourism in Brazil. Annals of Tourism Research, 29, 1138-1164.

[7] Burns, R.C. (2013) Tourism in Brazil: Environment, Management and Segments. G. Lohmann, D. Dredge (Eds.). Routledge, London and New York. Journal of Outdoor Recreation and Tourism, 3-4, 68-69.

[8] Brazil (1972) Decreto n. 70.355, de Abril de 1972. Cria o Parque Nacional da Serra da Canastra, no Estado de Minas Gerais, com os limites que especifica, e dá outras providências. http://legis.senado.gov.br/legislacao/ListaPublicacoes.action?id=121097

[9] Serra da Canastra (2005) Plano de Manejo do Parque Nacional da Serra da Canastra. http://www.serradacanastra.com.br

[10] Faccini, F., Piccazzo, M. and Robbiano, A. (2008) Environmental Geological Maps of San Fruttuoso Bay (Portofino Park, Italy). Journal of Maps, 2008, 431-443.

[11] Tomczyk, A.M. and Ewertowski, M. (2011) Degradation of Recreational Trails, Gorce National Park, Poland. Journal of Maps, 7, 507-518. http://dx.doi.org/10.4113/jom.2011.1195 
[12] IBAMA (2002) Bases, princípios e diretrizes: Diretoria de Unidades de Conservação e Vida Silvestre.

[13] Hendee, J.C., Stankey, G.H. and Lucas, R.C. (1990) Wilderness Management. 2nd Edition, North American Press, Golden, $537 \mathrm{p}$.

[14] Cesar, C.P. (2009) Instituto Brasileiro de Desenvolvimento Florestal: Um estudo evolutivo e das competências da instituição. http://www.if.ufrrj.br/inst/monografia/2009II/Cristopher.pdf

[15] Brazil (1974) Decreto n. 74.446, de 21 de Agosto de 1974. Dispõe sobre a criação de área prioritária de emergência, para fins de reforma agrária, no estado de Minas Gerais e dá outras providencias. http://legislacao.planalto.gov.br/legisla/legislacao.nsf/viwTodos/C7BF7C38B83943CB032569FA005AE476?Opendoc ument

[16] Brazil (1974) Decreto n. 74.447, de 21 de Agosto de 1974. Declara de interesse social, para fins de desapropriação, imóveis rurais situados nos municípios de Vargem Bonita, Sacramento e São Roque de Minas, compreendidos na área prioritária de emergência, para fins de reforma agraria, de que trata o decreto n. 74.446/1974.

http://legislacao.planalto.gov.br/legisla/legislacao.nsf/viwTodos/11B40FA7C9BFE04C032569FA005AE48E?Opendoc ument

[17] Batalha, M.A., Mantovani, W. and Mesquita-Junior, H.N. (1992) Vegetation Structure in Cerrado Physiognomies in South-Eastern Brazil. Brazilian Journal of Biology, 61, 475-483. http://dx.doi.org/10.1590/S1519-69842001000300018

[18] Uhlmann, A., Galvão, F. and Silva, S.M. (1998) Análise da estrutura de duas unidades fitofisionômicas de savana (cerrado) no sul do Brasil. Acta Botanica Brasilica, 12, 231-247. http://dx.doi.org/10.1590/S0102-33061998000300005

[19] Batalha, M.A. and Mantovani, W. (2000) Reproductive Phenological Patterns of Cerrado Plant Species at the Pede-Gigante Revserve (Santa Rita do Passa Quatro/SP, Brasil): A Comparison between the Herbaceous and Woody Floras. Revista Brasileira de Biologia, 60, 129-145. http://dx.doi.org/10.1590/S0034-71082000000100016

[20] Santos, S.B. (2009) Plano de Uso Público do Parque Nacional da Serra da Canastra. Federal University of Lavras (Monograph).

[21] Bueno, B.A.A., Nunes, M.R. and Melo, C. (2012) Bills Favor Mining and Threaten Conservation of Brazilian Merganser (Mergus octosetaceus) at Serra da Canastra National Park, Minas Gerais, Brazil. Natureza \& Conservação, 10, 64-71. http://dx.doi.org/10.4322/natcon.2012.011

[22] Novo, E.M.L.M. (1998) Sensoriamento Remoto: Princípios e Aplicações. 2nd Edition, Edgar Blucher, São Paulo.

[23] Moreira, M.A. (2005) Fundamentos do Sensoriamento Remoto e Metodologias de Aplicação. Ed. UFV, Viçosa.

[24] Jensen, J.R. (2009) Sensoriamento remoto do ambiente: Uma perspectiva em recursos terrestres. Translated by: Epiphanio, J.C.N., Formaggio, A.R., Santos, A.R., Rudorff, B.F.T., Almeida, C.M., Galvão, L.S., Parêntese, São José dos Campos, $598 \mathrm{p}$

[25] Ravera, F., Tarrason, D. and Espelta, J.M. (2015) Land Use Change Trajectories, Conservation Status and Social Importance of Dry Forests in Nicaragua. Environmental Conservation, 42, 1-11. http://dx.doi.org/10.1017/S0376892914000186

[26] Owen, H.J.F., Duncan, C. and Pettorelli, N. (2015) Testing the Water: Detecting Artificial Water Points Using Freely Available Satellite Data and Open Source Software. Remote Sensing in Ecology and Conservation, 1, 61-72. http://onlinelibrary.wiley.com/doi/10.1002/rse2.5/abstract

[27] Carver, S. (1991) Integrating Multi-Criteria Evaluation with Geographical Information Systems. International Journal of Geographical Information Systems, 5, 321-339. http://dx.doi.org/10.1080/02693799108927858

[28] Jankowski, P. (1995) Integrating Geographical Information Systems and Multiple Criteria Decision-Making Methods. International Journal of Geographical Information Systems, 9, 251-273. http://dx.doi.org/10.1080/02693799508902036

[29] Malczewski, J. (1999) GIS and Multicriteria Decision Analysis. John Wiley \& Sons, New York.

[30] Valladares, G.S. and Faria, A.L.L. (2004) SIG na análise do risco de salinização na Bacia do Rio Coruripe, AL. Engevista, 6, 86-98. http://www.uff.br/engevista/seer/index.php/engevista/article/view/147/50

[31] Bonham-Carter, G.F. (1994) Geographic Information Systems for Geoscientists: Modelling with GIS. Pergamon, Oxford.

[32] Riad, P.H.S., Billib, M., Hassan, A.A., Salam, M.A. and El Din, M.N. (2011) Application of the Overlay Weighted Model an Boolean Logic to Determine the Best Locations for Artificial Recharge of Groundwater. Journal of Urban and Environmental Engineering, 5, 57-66. http://dx.doi.org/10.4090/juee.2011.v5n2.057066

[33] USGS-United States Geological Survey (2000) Data Pool.

[34] Silva, J.X. and Zaidan, R.T. (2004) Geoprocessamento e Análise Ambiental: Aplicações. Bertrand Brazil, Rio de Janeiro, 368 p. 